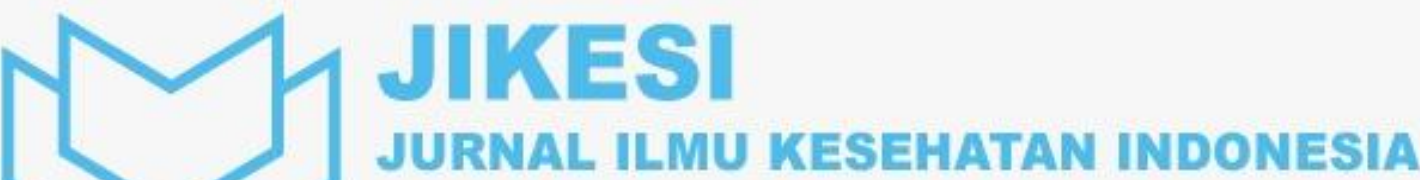 \\ (Indonesian Journal of Health Science)
}

Artikel Penelitian

\section{Hubungan Kadar Cancer Antigen 15-3 Serum dengan Metastasis Kanker Payudara}

\author{
Fakhriyyatur Rahmi $\mathrm{M}^{1}$, Rikarni ${ }^{2}$, Nora Harminarti ${ }^{3}$ \\ ${ }^{1}$ Profesi Dokter Fakultas Kedokteran Universitas Andalas, Padang, Indonesia \\ ${ }^{2}$ Bagian Patologi Klinik Fakultas Kedokteran Universitas Andalas/RSUP Dr M Djamil Padang, Indonesia \\ ${ }^{3}$ Bagian Parasitologi Fakultas Kedokteran Universitas Andalas/RSUP DR M Djamil Padang, Indonesia
}

\section{A B S T R A C T}

\begin{abstract}
Pendahuluan: CA 15-3 serum merupakan salah satu penanda tumor untuk melihat respon terapi, prognosis serta metastasis dari kanker payudara yang direkomendasikan oleh American Society of Clinical Oncology. CA 15-3 serum merupakan mucin yang kadarnya akan di ekspresikan secara berlebihan oleh sel kanker payudara. Ekspresi berlebihan dari CA 15-3 serum akan terjadi jika progresifitas sel meningkat. Beberapa penelitian menunjukan peningkatan CA $15-3$ serum pada kejadian metastasis kanker payudara.
\end{abstract}

Objektif: Penelitian ini bertujuan untuk mengetahui hubungan antara kadar CA 15-3 serum dengan metastasis kanker payudara. Metode penelitian menggunakan desain cross sectional, retrospektif pada pasien kanker payudara di RSUP Dr M Djamil.

Metode: Pengambilan sampel menggunakan teknik consequtive sampling dengan jumlah sampel 46 orang. Analisis data menggunakan uji Mann-Whitney.

Hasil: Kanker payudara yang mengalami metastasis jauh terbanyak pada rentang usia 40-60 tahun sebanyak $65,21 \%$ dan yang mengalami metastasis ke kelanjar getah bening sebanyak 86,96\%. Rerata kadar CA 15-3 serum lebih tinggi pada kelompok metastasis jauh 385,0439 U/mL dibandingkan dengan kelompok tanpa metastasis jauh. Kelompok metastasis jauh paling banyak mengalami tipe tunggal $(69,6 \%)$ dengan rerata CA $15-3$ serum $472,24 \mathrm{U} / \mathrm{mL}$. Organ target paling banyak adalah paru $(69,9 \%)$. Rerata CA 15-3 serum paling tinggi pada pleura sebesar 557,2 $\mathrm{U} / \mathrm{mL}$.

Kseimpulan: Terdapat hubungan yang bermakna antara rerata kadar CA 15-3 serum dengan metastasis kanker payudara $(p=0.000)$.

Kata Kunci: CA 15-3 serum, kanker payudara, metastasis

Background: CA 15-3 serum is one of the tumor marker that has been recommended by American Soviety of Clinical Oncology to show the response of the therapy, prognosis and metastasis of the breast cancer. CA 15-3 serum is a mucin that will be expressed by breast cancer cell. The over expression of CA 15-3 serum can be occurred if the cell progressivity is increase. Several studies have shown that CA 15-3 serum is increasing in metastasis breast cancer.

Objective: This study aimed to determine the relationship between the CA 15-3 serum with metastasis breast cancer. Methods: This study used a cross sectional design in breast cancer patient at Dr. M Djamil Hospital. Sampling using consequtive sampling technique with a total sample of 46 people. Data was analyzed by using Mann-Whitney test.

Results: Distant metastasis of Breast cancer was more common in age group of $40-60$ years $(65,21 \%)$ and $86,96 \%$ had shown a lymphatic metastasis. The mean of CA 15-3 serum was higher in the group with distant metastasis $385,0439 \mathrm{U} / \mathrm{mL}$ compared to group without distant metastasis. Distant metastasis was more common in single state metastasis (69,6\%) with the mean $472,24 \mathrm{U} / \mathrm{mL}$. Common targeting organ of the distant metastasis was lung (69,9\%). The highest mean of CA 15-3 serum was in pleura $557,2 \mathrm{U} / \mathrm{mL}$.

Conclusion: There was a statistically significant relationship between the mean of CA 15-3 serum with metastasis breast cancer $(p=0.000)$.

Keywords: CA 15-3 serum, Breast cancer, metastasis

Apa yang sudah diketahui tentang topik ini?

Kanker Payudara

Tumor Marker

\section{Apa yang ditambahkan pada studi ini?}

Hubungan kadar Ca 15-3 serum dengan metastasis kanker payudara

\section{CORRESPONDING AUTHOR}

Phone: +62(82284010068)

E-mail: rahmi.rafand@gmail.com

\section{ARTICLE INFORMATION}

Received: August $15^{\text {th }}, 2020$

Revised: April 15 ${ }^{\text {th }}, 2021$

Available online: May $27^{\text {th }}, 2021$ 


\section{Pendahuluan}

Kanker payudara merupakan keganasan pada jaringan payudara yang dapat berasal dari epitel duktus maupun lobulusnya. ${ }^{1}$ Kanker Payudara merupakan salah satu jenis keganasan terbanyak pada wanita di seluruh dunia termasuk Indonesia. Menurut publikasi statistik dari Global Burden Cancer (GLOBOCAN) tahun 2018 dan International Agency for Research on Cancer (IARC), sebanyak 2,1 juta wanita di dunia didiagnosis menderita kanker payudara, 627.000 diantaranya atau sekitar 6,6\% meninggal karena penyakit tersebut. ${ }^{2}$ Data GLOBOCAN 2018 menyebutkan bahwa insiden baru kanker payudara di Indonesia mencapai $16,7 \%$ dari total kejadian kanker di Indonesia atau setara dengan 58.256 kasus. $^{4}$ Data Kementrian Kesehatan Republik Indonesia tahun 2013, menunjukan provinsi Sumatera Barat menduduki peringkat ketiga di Indonesia dengan prevalensi mencapai 0,9\%o dan jumlah pasien absolut yang terdiagnosis mencapai 2.285 kasus. $^{5}$

Kanker payudara merupakan penyebab kematian nomor lima dari seluruh kematian akibat kanker di dunia, serta penyebab kematian terbanyak penderita kanker pada wanita. Kematian akibat kanker pada negara berkembang lebih tinggi insidennya dibandingkan dengan negara maju, meskipun jumlah penderita kanker lebih tinggi pada negara maju. ${ }^{3}$ Tingginya angka kematian akibat kanker pada negara berkembang ini diantaranya disebabkan oleh terlambatnya diagnosis serta prognosis yang buruk. ${ }^{2,3}$ Kejadian kematian akibat kanker payudara terus meningkat sejak tahun 1990. Pada tahun 2010 di Belanda didapatkan rasio 1 berbanding 6,6 wanita yang terkena kanker payudara setiap tahunnya, sementara risiko kematian akibat kanker payudara di Belanda mencapai 1 berbanding 27 wanita. Data di Indonesia sendiri belum ada. Salah satu penyebab kematian pada pasien kanker payudara adalah karena terjadinya metastasis. ${ }^{3}$

Metastasis pada kanker payudara merupakan suatu migrasi dari sel-sel ganas payudara ke jaringan lain tubuh. Metastasis menunjukan terbentuknya suatu implan sekunder yang terletak jauh dari tumor primer. Metastasis kanker payudara bisa menyebar secara limfogen ke kelenjar getah bening, dan secara hematogen ke organ lainnya. ${ }^{6}$ Organ terbanyak yang mengalami metastasis jauh dari kanker payudara diantaranya adalah tulang (40-75\%), paru (5$15 \%)$, pleura $(5-15 \%)$, hati $(3-10 \%)$ dan otak (kecil dari 5\%). Metastasis secara hematogen maupun limfogen menjadi ancaman yang serius bagi penderita kanker payudara. ${ }^{7}$

Pemeriksaan serum tumor marker atau penanda tumor pada pasien kanker payudara telah digunakan secara luas sebagai salah satu tindakan non-invasif untuk mengukur respon terapi, kekambuhan serta prognosis dari kanker payudara. Tumor marker yang sering digunakan adalah Cancer Antigen 15-3 (CA 15-3). CA 15-3 serum adalah sebuah glikoprotein yang terdapat pada kelenjar mammae dan beberapa tempat lainnya seperti ovarium, pankreas, paru dan kolorektal. ${ }^{8}$ CA 15-3 serum merupakan suatu mucin yang kadar nya akan di ekspresikan secara berlebihan oleh sel yang mengalami keganasan. Kadar CA 15-3 serum akan meningkat lebih dari $30 \mathrm{U} / \mathrm{mL}$ pada keadaan keganasan, seperti kanker payudara. ${ }^{9}$

American Society of Clinical Oncology (ASCO) mengatakan bahwa pemeriksaan CA 15-3 tidak direkomendasikan untuk skrining awal pada kanker payudara, karena CA15-3 dinilai kurang sensitif pada tahap awal kanker payudara. Penggunaan CA 15-3 serum direkomendasikan oleh ASCO untuk melihat apakah ada kemungkinan terjadi metastasis atau tidak. ${ }^{10}$

Penelitian yang dilakukan oleh Fejzic et al tahun 2015 menyebutkan bahwa terdapat peningkatan kadar CA 15-3 serum pada pasien kanker payudara yang mengalami metastasis jauh. ${ }^{9}$ Penelitian yang dilakukan oleh Geng et al tahun 2014 menyebutkan bahwa dari total 136 pasien yang didiagnosis dengan metastasis tunggal pada kanker payudara, hampir setengahnya mengalami peningkatan kadar CA 15-3 serum. Kejadian metastasis jauh terbanyak merupakan metastasis ke paru. ${ }^{11}$ Saat ini belum ada penelitian tentang hubungan peningkatan kadar CA 15-3 serum pada pasien metastasis jauh kanker payudara di RSUP. DR. M. Djamil Padang. Berdasarkan uraian diatas, peneliti tertarik untuk meneliti hubungan antara rerata kadar CA 15-3 serum dengan kejadian metastasis kanker payudara di RSUP. Dr. M. Djamil Padang.

\section{Metode}

Jenis penelitian yang digunakan adalah analitik komparatif dengan menggunakan studi 
retrospektif dengan metode cross sectional untuk mengetahui hubungan kadar CA 15-3 serum dengan metastasis jauh pada kanker payudara. Data diambil menggunakan data sekunder pasien kanker payudara di RSUP DR. M. Djamil Padang.

Penelitian dilakukan dari bulan Januari 2019 sampai dengan bulan April 2019 di Laboratorium Sentral RSUP DR M Djamil Padang.

Populasi pada penelitian ini adalah pasien kanker payudara yang didiagnosis oleh klinisi dan mendapatkan perawatan di RSUP. DR. M. Djamil Padang tahun 2017 dan 2018.

Sampel pada penelitian ini adalah populasi yang memenuhi kriteria inklusi dan ekslusi. Untuk kriteria inklusi adalah pasien kanker payudara yang didiagnosis oleh klinisi di RSUP Dr. M. Djamil Padang dan melakukan pemeriksaan kadar CA 15-3 serum sedangkan untuk kriteria ekslusi adalah sebagai berikut; Kanker payudara pada laki-laki, Penyakit hepar, Penyakit payudara jinak serta keganasan primer pada organ lain (paru, hati, ovarium, endometrium, gastrointestinal, kandung kemih, kolorektal dan pankreas)

Pengambilan sampel menggunakan teknik consequtive sampling dengan total sampel sebanyak 46 orang dibagi atas dua kelompok.

Analisis Univariat dilakukan untuk mendapatkan gambaran karakteristik untuk masing-masing variabel, seperti kadar serum tumor marker CA 15-3 dan kejadian metastasis pada kanker payudara. Hasil dari analisis ini akan menghasilkan distribusi frekuensi dari setiap variabel.

Analisis bivariat dilakukan untuk mendapatkan hubungan antara kadar serum tumor marker CA 15-3 dengan kejadian metastasis pada kanker payudara dengan menggunakan analisis uji $t$-test independent untuk data kategorik dan numerik. Apabila Distribusi data tidak normal maka uji diganti menjadi uji non-parametrik Mann-Whitney.

\section{Hasil}

Pengambilan data penelitian dilakukan di Instalasi Rekam Medik, Laboratorium Sentral dan bagian Bedah Onkologi RSUP Dr M Djamil Padang. Selama periode Januari 2017 sampai dengan Mei 2019 terdapat 46 pasien Kanker payudara yang memeriksa kadar CA 15-3 serum yang memenuhi kriteria inklusi.

https://doi.org/10.25077/jikesi.v1i3.110

\section{Karakteristik Pasien Kanker Payudara}

Tabel 1. Distribusi Frekuensi Karakteristik Pasien Kanker Payudara

\begin{tabular}{lcccc}
\hline Karakteristik & \multicolumn{3}{c}{ Metastasis Jauh } & \multicolumn{2}{c}{$\begin{array}{c}\text { Tidak } \\
\text { Metastasis } \\
\text { Jauh }\end{array}$} \\
& f & \% & f & \% \\
\hline $\begin{array}{c}\text { Umur } \\
\quad<40 \text { tahun }\end{array}$ & 3 & 13,04 & 9 & 39,13 \\
$\quad 40-60$ tahun & 15 & 65,21 & 11 & 47,83 \\
$\quad>60$ tahun & 5 & 21,75 & 3 & 13,04 \\
\hline Jumlah & 23 & 100 & 23 & 100 \\
\hline Metastasis KGB & & & & \\
$\quad$ Ada & 20 & 86,96 & 6 & 26,09 \\
Tidak Ada & 3 & 13,04 & 17 & 73,91 \\
\hline Jumlah & 23 & 100 & 23 & 100 \\
\hline
\end{tabular}

Karakteristik pasien kanker payudara yang memeriksa kadar CA 15-3 serum pada kelompok metastasis jauh berdasarkan umur paling banyak di derita pada usia 40-60 tahun sebanyak 15 pasien $(65,21 \%)$ diikuti oleh usia lebih dari 60 sebanyak 5 pasien $(21,75 \%)$ dan paling sedikit pada usia kurang dari 40 tahun sebanyak 3 pasien $(13,04 \%)$. Sebaran metastasis ke KGB pada kelompok dengan metastasis jauh sebanyak 20 pasien $(86,96 \%)$ sedangkan yang tidak mengalami metastasis KGB sebanyak 3 pasien $(13,04 \%)$. (Tabel 1)

Pada kelompok tanpa metastasis jauh, kelompok usia paling banyak adalah rentang usia 40-60 tahun sebanyak 11 pasien $(47,83 \%)$ diikuti oleh kelompok usia kecil dari 40 tahun sebanyak 9 pasien $(39,13 \%)$ dan kelompok usia lebih dari 60 tahun 3 pasien $(13,04 \%)$. Sebaran metastasis ke KGB pada kelompok pasien kanker payudara tanpa metastasis ke organ target sebanyak 6 pasien $(26,09 \%)$ sedangkan yang tidak mengalami sebaran metastasis ke KGB sebanyak 17 pasien $(73,91 \%)$. (tabel 1)

\section{Kadar CA 15-3 Serum Pada Pasien Kanker Payudara dengan Metastasis Jauh dan Tidak Mengalami Metastasis Jauh}

Tabel 2. Rerata Kadar CA 15-3 serum pada pasien kanker payudara dengan metastasis jauh dan tidak mengalamii metastasis jauh.

\begin{tabular}{lc}
\hline \multicolumn{1}{c}{ Kanker Payudara } & Rerata (U/mL) \\
\hline Metastasis Jauh & 385,04 \\
Tidak Metastasis Jauh & 67,07 \\
\hline
\end{tabular}


Rerata kadar CA 15-3 serum pada kanker payudara dengan metastasis jauh sebesar 385,04 $\mathrm{U} / \mathrm{mL}$ sedangkan pada kanker payudara yang tidak metastasis jauh sebesar 67,07 U/mL. (Tabel 2)

\section{Rerata Kadar CA 15-3 Serum Pada Pasien Kanker Payudara Sesuai Tipe Tunggal dan Multipel}

Tabel 3. Rerata Kadar CA 15-3 Pasien Metastasis Jauh Sesuai Tipe Tunggal dan Multipel

\begin{tabular}{lc}
\hline Tipe Metastasis Jauh & Rerata (U/mL) \\
\hline Metastasis Tunggal & 472,24 \\
Metastasis Multipel & 185,74 \\
\hline
\end{tabular}

Rerata kadar CA 15-3 serum pada metastasis tunggal yaitu $472,24 \mathrm{U} / \mathrm{ml}$ sedangankan pada metastasis multipel sebanyak 185,74 U/ml. (Tabel 3)

4. Rerata Kadar CA 15-3 Serum pada Pasien Kanker Payudara Berdasarkan Target Organ Metastasis

Tabel 4. Rerata Kadar CA 15-3 Serum pada Pasien Kanker Payudara Berdasarkan Organ Target Metastasis

\begin{tabular}{cc} 
Target Organ Metastasis Jauh & Rerata (U/mL) \\
\hline Organ Target & \\
Paru & 439,84 \\
Pleura & 557,2 \\
Hati & 551,15 \\
Organ lain & 284,3 \\
Metastasis Multipel & 185,74 \\
\hline
\end{tabular}

Rerata kadar CA 15-3 serum pada organ terget metastasis terbanyak pada pleura 557,2 $\mathrm{U} / \mathrm{mL}$ lalu diikuti oleh hati 551,15 $\mathrm{U} / \mathrm{mL}$ dan paru sebanyak 439,84 U/mL. (Tabel 4)

\section{Distribusi Frekuensi Pasien Kanker Payudara dengan Metastasis Jauh Berdasarkan Tipe Tunggal dan Multipel}

Tabel 5. Distribusi Frekuensi Pasien Kanker Payudara dengan Metastasis Jauh Berdasarkan Tipe Tunggal dan Multipel

\begin{tabular}{ccc}
\hline Tipe Metastasis Jauh & f & \% \\
\hline Metastasis Tunggal & 16 & 69,6 \\
Metastasis Multipel & 7 & 30,4 \\
\hline Jumlah & 23 & 100 \\
\hline
\end{tabular}

Distribusi frekuensi pasien kanker payudara dengan metastasis jauh berdasarkan tipe tunggal atau tipe multipel. Sebanyak 16 pasien $(69,6 \%)$ yang mengalami metastasis jauh memiliki tipe metastasis tunggal pada satu organ dan yang mengalami tipe multipel sebanyak 7 pasien $(30,4 \%)$ dari total 23 sampel yang mengalamii metastasis jauh kanker payudara.(Tabel 5)

\section{Distribusi Frekuensi Pasien Kanker Payudara yang Bermetastasis Jauh Berdasarkan Organ Target}

Tabel 6. Distribusi Frekuensi Pasien Kanker Payudara dengan Metastasis Jauh Berdasarkan Organ Target.

\begin{tabular}{|c|c|c|}
\hline Organ Target & f & $\%$ \\
\hline \multicolumn{3}{|l|}{ Tulang } \\
\hline $\mathrm{Ya}$ & 2 & 8,7 \\
\hline Tidak & 21 & 91,3 \\
\hline Total & 23 & 100 \\
\hline \multicolumn{3}{|l|}{ Paru } \\
\hline $\mathrm{Ya}$ & 16 & 69,9 \\
\hline Tidak & 7 & 30,4 \\
\hline Total & 23 & 100 \\
\hline \multicolumn{3}{|l|}{ Pleura } \\
\hline $\mathrm{Ya}$ & 1 & 4,3 \\
\hline Tidak & 22 & 95,7 \\
\hline Total & 23 & 100 \\
\hline \multicolumn{3}{|l|}{ Hati } \\
\hline Ya & 10 & 43,5 \\
\hline Tidak & 13 & 56,5 \\
\hline Total & 23 & 100 \\
\hline \multicolumn{3}{|l|}{ Otak } \\
\hline Ya & 2 & 8,7 \\
\hline Tidak & 21 & 91,3 \\
\hline Total & 23 & 100 \\
\hline \multicolumn{3}{|l|}{ Dan Lain-lain } \\
\hline $\mathrm{Ya}$ & 1 & 4,3 \\
\hline Tidak & 22 & 95,7 \\
\hline Total & 23 & 100 \\
\hline
\end{tabular}

Distribusi frekuensi kelompok pasien kanker payudara yang mengalami metastasis berdasarkan organ target terdapat 2 pasien $(8,7 \%)$ yang mengalami metastasis ke tulang. Dari total 23 pasien terdapat 16 pasien $(69,9 \%)$ yang mengalami metastasis ke Paru. Terdapat 1 orang pasien $(4,3 \%)$ mengalami metastasis ke pleura. Sebanyak 10 orang pasien $(43,5 \%)$ mengalami metastasis ke hati dan dari 23 sampel hanya 2 pasien $(8,7 \%)$ yang mengalami metastasis ke otak. Terdapat 1 orang pasien yang mengalami 
metastasis ke organ lain selain 5 organ terbanyak. (Tabel 6)

\section{Hubungan Kadar CA 15-3 Serum dengan Metastasis Kanker Payudara}

Tabel 7. Hubungan Kadar CA 15-3 serum dengan Metastasis Jauh Kanker Payudara

\begin{tabular}{ccc}
\hline & Mean rank & p-Value \\
\hline Metastasis Jauh & 31,02 & 0.000 \\
Tidak Metastasis Jauh & 15,98 & \\
\hline
\end{tabular}

Analisis bivariat dilakukan untuk mengetahuii hubungan antara kadar CA 15-3 serum dengan metastasis kanker payudara. Uji statistik pada penelitian analitik komparatif ini adalah uji Mann-Whitney. $p$-value $=0.000(\mathrm{p}<0.05)$ sehingga dapat disimpulkan bahwa secara statistika terdapat hubungan yang bermakna antara kadar CA 15-3 serum dengan metastasis kanker payudara. (Tabel 7)

\section{Pembahasan}

Hasil penelitian yang telah dilakukan menunjukkan karakteristik umur pada kelompok pasien kanker payudara yang mengalami metastasis lebih banyak pada kelompok umur 40 hingga 60 tahun yaitu 15 pasien $(65,21 \%)$. Pada kelompok pasien tanpa metastasis jauh ditemukan lebih banyak pada usia 40-60 tahun sebanyak 11 pasien (47,83\%). Penelitian ini sejalan dengan penelitian yang dilakukan oleh Chen et al menyatakan bahwa terdapatnya hubungan kelompok usia 40-59 tahun dan diatas 60 tahun dengan kejadian kanker payudara dengan nilai $\mathrm{p}=0,0001 .{ }^{12}$

Penelitian yang telah dilakukan oleh Chen et al tahun 2016 menunjukan bahwa pada rentang usia 40-60 tahun lebih besar risiko untuk terkena kanker payudara di bandingkan dengan kelompok usia $<40$ tahun dengan tipe kanker yang tidak terlalu agresif dan berespon terhadap terapi. ${ }^{12}$

Sharma et al dalam penelitiannya mengemukakan usia yang lebih kecil dari 40 tahun cenderung memiliki stadium yang lebih tinggi atau stadium III dan IV dibandingkan dengan usia diatas 40 tahun sehingga angka kematian pada kasus kanker payudara pada usia kurang dari 40 tahun cenderung lebih tinggi. ${ }^{13}$ Hal ini dikarenakan sebagian besar kanker pada usia kurang dari 40 tahun memiliki triple negative
ER, PR dan HER 2 (-). Pada usia kurang dari 40 tahun, subtipe sel yang paling banyak ditemui adalah Luminal B dengan ekspresi Ki67 yang sangat meningkat. Pada usia lebih dari 40 tahun subtipe yang paling banyak ditemui adalah Luminal A dengan ekspresi Ki67 yang lebih rendah. ${ }^{14}$

Hasil penelitian menunjukkan bahwa pada kelompok dengan metastasis jauh dengan total 23 sampel terdapat 20 orang $(86,96 \%)$ mengalami metastasis ke KGB. Pada kelompok tanpa metastasis jauh juga mengalami metastasis KGB lebih banyak yaitu 17 orang $(73,91 \%)$ dari total 23 sampel. Hasil penelitian ini sejalan dengan penelitian yang dilakukan oleh Valic et al yang mendapatkan bahwa hanya 2,9\% pasien yang tidak mengalami metastasis kanker payudara ke kelenjar getah bening.. ${ }^{8}$

Perbedaan kapasitas dalam metastasis bisa dipengaruhi oleh faktor keturunan dan latar belakang gen yang memengaruhi. Gen yang telah teridentifikasi sebagai gen pencetus metastasis diantaranya, Bromodomain-Containing Protein 4 (BRD4), Breast Cancer Metastasis Suppressor 1 (BRMS1), Checkpoint Kinase 2 (CHEK2), Glutathione Peroxidase 4 (GPX4), Ligase IV DNA ATP-dependent (LIG4), NAD(P)H Dehydrogenase, Quinone 1 (NQ01), Ribosomal RNA-Processing Protein 1 (RRP1B), Signal-induced ProliferationAssociated Gene 1 (SIPA1), and Tumor Protein p73 (TP73). Varian DNA gen yang menjadi pencetus terjadinya metastasis memberikan hasil yang berbeda tiap individu tergantung lingkungan mikro setiap gen yang mempengaruhi perbedaan ekspresi tiap gen. ${ }^{17}$

Peningkatan ukuran tumor akan memicu meningkatnya tekanan cairan intersisial dan intertumoral dan cairan intersisial akan dilepaskan saat sistem berupaya untuk mencapai titik homeostasis. Pembuluh darah limfatik lebih permeabel jika dibandingkan dengan pembuluh darah lainnya. Laju aliran pada pembuluh darah limfatik juga lebih lambat 100-500 kali dibandingkan dengan pembuluh darah lainnya serta tegangan geser pembuluh limfatik yang lebih rendah karena adanya vasodilatasi. Oleh karena itu, rute penyebaran sel kanker lewat jalur limfatik lebih unggul dalam memfasilitasi penyebaran sel tumor. ${ }^{15}$

Rerata kadar CA 15-3 serum pada metastasis lebih tinggi dibandingkan dengan 
kadar CA 15-3 serum pada kanker payudara yang tidak mengalami metastasis yakni sebesar 385,0439 U/mL dan 67,07 U/mL. Penelitian yang dilakukan oleh Obenauf et al didapatkan bahwa rerata kadar CA 15-3 serum pada pasien kanker payudara adalah $30,67 \mathrm{U} / \mathrm{mL}$, sedangkan rerata kadar CA 15-3 serum pada pasien kanker payudara tanpa metastasis sebesar $18,36 \mathrm{U} / \mathrm{mL}$. Hal ini berbeda dengan hasil penelitian yang didapatkan dimana kadar CA 15-3 serum jauh lebih tinggi pada metastasis payudara. ${ }^{16}$

Rerata kadar CA 15-3 serum pada kelompok pasien yang mengalami metastasis jauh tunggal lebih tinggi dengan mean $472,24 \mathrm{U} / \mathrm{mL}$, sedangkan kelompok yang mengalami metastasis jauh tipe multipel hanya memiliki rerata kadar CA 15-3 serum yang lebih rendah sebesar 185,74 $\mathrm{U} / \mathrm{mL}$. Hasil penelitian berbanding terbalik dengan penelitian oleh Geng et al dimana CA 15-3 serum meningkat secara signifikan pada pasien kanker payudara dengan tipe metastasis jauh multipel. ${ }^{11}$ Penelitian yang dilakukan kali ini mendapatkan hasil yang berbeda dengan beberapa penelitian sebelumnya dimana kadar CA 15-3 lebih tinggi pada kelompok metastasis tunggal.

Beberapa aspek yang berpengaruh terhadap kadar CA 15-3 serum dalam tubuh pasien selain jumlah target organ adalah ukuran tumor, subtipe sel serta terapi. Ukuran tumor yang lebih besar dapat meningkatkan kadar CA 15-3 serum meskipun hanya mengalami metastasis pada satu target organ. ${ }^{18}$ Terapi juga dapat menurunkan ukuran tumor pada pasien kanker payudara sehingga kadar CA 15-3 serum lebih rendah. ASCO menjelaskan bahwa fungsi CA 15-3 serum sebagai pemantauan terapi. Kadar CA 15-3 serum akan kembali stabil jika terapi yang diberikan berhasil, sedangkan angka CA 15-3 akan terus naik jika terapi yang dilakukan tidak berhasil. ${ }^{19}$

Hasil rerata CA 15-3 serum pada penelitian inii didapatkan paling tinggi pada organ pleura $557,2 \mathrm{U} / \mathrm{mL}$ dan diikuti organ hati 551,15 $\mathrm{U} / \mathrm{mL}$. Hosseini et al mendapatkan rerata kada CA 15-3 serum pada metastasis ke tulang sebesar 68,8 U/mL, hati 66,8 U/mL dan paru 50,5 U/mL. ${ }^{10}$ Perbedaan hasil kadar CA 15-3 serum ini bisa dipicu oleh beberapa hal salah satu nya ukuran tumor dan pasien setelah terapi. Jika hasil dan respon terapi membaik maka kadar CA 15-3 akan menurun di beberapa target organ. ${ }^{18}$

Hasil penelitian yang telah dilakukan menunjukkan bahwa dari 23 sampel kelompok yang mengalami metastasis jauh ke organ, terdapat 16 pasien $(69,6 \%)$ pasien dengan tipe metastasis tunggal serta 7 pasien $(30,4 \%)$ dengan tipe metastasis multipel. Penelitian yang dilakukan oleh Geng et al menunjukan hal yang berbeda, dimana metastasis dengan tipe multipel lebih banyak di dapatkan sekitar 52,1\%. ${ }^{11}$

Perbedaan hasil penelitian tersebut dapat disebabkan oleh beberapa faktor seperti jumlah sampel, tipe sel dan gen pencetus pada tiap pasien. Tingkatan stadium dan terapi juga mempengaruhi tipe metastasis tunggal atau multipel. Metastasis merupakan suatu proses yang sangat terkait dengan genetik yang heterogen dari populasi sel sehingga bisa melakukan kolonisasi di organ target tertentu. Lingkungan mikro di tempat organ target juga sangat mempengaruhi berkembangnya metastasis baik pada satu organ target maupun banyak organ target. ${ }^{19}$

Penelitian yang telah dilakukan didapatkan distribusi frekuensi organ target pada metastasis jauh yaitu paru sebanyak 69,6\% dari total 23 sampel. Hasil penelitian ini berbeda dengan penelitian yang dilakukan oleh Geng et al dimana organ paling banyak yang terkena penyebaran metastasis kanker payudara adalah tulang $(23,2 \%)$, kemudian diikuti oleh paru $(9,9 \%) \cdot{ }^{11}$

Penelitian yang telah dilakukan menunjukan hasil yang berbeda dengan beberapa penelitian lain sebelumnya, dimana metastasis jauh paling banyak pada organ tulang dikarenakan lingkungan mikro pada tulang lebih baik untuk perkembangan sel kanker. Salah satu perbedaan dari dua penelitian sebelumnya adalah dari segi jumlah sampel. Pada penelitian Geng et al, jumlah sampel yang di teliti adalah sebanyak 284 sampel sedangkan pada penelitian ini jumlah sampel untuk kelompok yang mengalami metastasis hanya 23 sampel. Terdapat kemungkinan besar terambilnya kelompok sampel dengan metastasis paru lebih banyak pada penelitian ini. Jumlah sampel yang makin besar memungkinkan untuk melihat sebaran metastasis kanker secara lebih luas. ${ }^{11}$

Kanker payudara lebih cenderung bermetastasis jauh ke tulang karena lingkungan 
yang kaya dengan nutrisi dan juga adanya interaksi antara sel kanker dengan osteoblas maupun osteoklas. Interaksi ini akan menstimulasi resorpsi tulang dan meningkatkan tumor-promoting factor yang selanjutnya akan membentuk sel kanker. Metastasis jauh ke tulang terkadang tidak memiliki gejala yang khas pada awal terbentuk metastasis. Penelitian serupa juga dipaparkan oleh Fejzic et al dimana lokasi target organ paling banyak yang mengalami metastasis jauh adalah tulang $(52,6 \%)$ lalu diikuti oleh paru. ${ }^{9}$

Hati merupakan salah satu organ yang banyak mendapatkan vaskularisasi, baik dari vena porta maupun aliran sirkulasi sistemik. Sel kanker payudara dapat bermetastasis ke hati melalui aliran darah arteri setelah melewati paru. Kejadian metastasis jauh ke otak pada kanker payudara hanya berkisar $5 \%$ dari total pasien yang mengalami metastasis jauh. Hal ini juga sama dengan penelitian yang dilakukan oleh Geng et al dimana hanya $1,8 \%$ dari total seluruh pasien metastasis jauh kanker payudara yang menyebar ke otak. ${ }^{11}$

Sel kanker payudara dapat bermetastasis ke hati melalui aliran darah arteri setelah melewati paru. Gejala metastasis ke hati tidak cepat timbul dikarenakan adanya kompensasi yang dilakukan oleh hati terlebih dahulu. Jenis sel parenkim hati tertentu mendukung pertumbuhan sel metastasis dari kanker payudara. Interaksi sel kanker payudara dan hepatosit menyebabkan induksi c-Met dan merangsang metastasis ke hati dengan bantuan mediasi dari claudin-2. ${ }^{16}$

Metastasis jauh ke otak biasanya muncul pada tahap akhir dari kanker payudara dan stadium lanjut serta sangat berhubungan dengan prognosis yang sangat buruk. Pasien dengan metastasis jauh ke otak biasanya memiliki beberapa gejala klinis seperti sakit kepala, rasa haus, nyeri kuduk bergantung pada bagian mana yang terserang. Faktor risiko yang bisa meningkatkan kejadian metastasis jauh ke otak diantaranya, usia yang relatif muda, status ER(-), diferensiasi sel yang jelek dan overexpression dari HER2. ${ }^{16}$

Hasil uji statistik dilakukan dengan menggunakan uji Mann-Whitney di peroleh $p$ value $=0.000(\mathrm{p}<0.05)$. Berdasarkan hasil uji yang telah dilakukan dapat disimpulkan bahwa secara uji statistik terdapat hubungan yang bermakna antara rerata kadar CA 15-3 serum dengan metastasis kanker payudara. Penelitian oleh Geng et al juga menunjukan adanya hubungan yang bermakna antara kejadian metastasis dengan kenaikan kada CA 15-3 (p=0.001).11 CA 15-3 serum juga ditemukan terkait dengan adesi sel pada metastasis kanker payudara. Darlix et al juga melaporkan bahwa peningkatan kadar Cancer Antigen 15-3 serum meningkat pada kejadian metastasis kanker payudara. ${ }^{20}$

Substansi yang diproduksi oleh sel kanker atau yang dieksresikan dan dilepaskan oleh sel jinak yang berada di sekitar sel kanker sebagai respon terhadap adanya kanker pada umumnya berbentuk makromolekul atau protein dengan komponen karbohidrat atau lipid yang kadarnya didalam darah dapat diukur. CA 15-3 adalah salah satu substansi pertanda diferensiasi. Sel ganas pada payudara akan memproduksi substansi tersebut secara berlebihan sehingga bisa diukur di dalam darah. Kadar CA 15-3 akan meningkat jika kanker payudara menjadi sangat progresif, hal tersebut bisa mendatangkan kecurigaan timbulnya relaps atau metastasis pada kanker payudara. Penggunaan CA 15-3 serum sangat bermanfaat untuk memantau pasien pasca operasi, pasien yang mengalami kekambuhan dan pasien yang memiliki metastasis. ${ }^{21}$

\section{Simpulan}

Kanker payudara yang dengani metastasis jauh paling banyak terjadi pada rentang usia 4060 tahun diantaranya mengalami metastasis ke KGB. Rerata CA 15-3 serum lebih tinggi pada kelompok dengan metastasis jauh dibandingakan dengan kelompok tanpa metastasis jauh. Kelompok metastasis jauh paling banyak mengalami tipe tunggal dengan rerata CA 15-3 serum yang tinggi. Organ target metastasis paling banyak adalah paru. Rerata CA 15-3 serum paling tinggi terdapat pada metastasis ke pada pleura. Terdapat hubungan yang bermakna secara statistik antara rerata kadar CA 15-3 serum dengan metastasis kanker payudara.

Penelitian selanjutnya diharapkan untuk menambah jumlah sampel dan melakukan pemeriksaan CA 15-3 serum sebelum dan sesudah tindakan pengobatan agar didapatkan hasil pengukuran CA 15-3 serum yang lebih maksimal 


\section{Ucapan Terima Kasih}

Penulis mengucapkan terimakasih kepada semua pihak yang telah memberikan bimbingan, bantuan dan motivasi kepada penulis sehingga penulis dapat menyelesaikan penelitian ini.

\section{Daftar Pustaka}

1. Kementrian Kesehatan Republik Indonesia. Panduan penatalaksanaan kanker payudara. 2018 (diunduh Februari 2019). Tersedia dari: http://kanker.kemkes.go.id/guidelines/PPKPayudara. pdf

2. GLOBOCAN. Cancer fact sheets. 2018. (diunduh Februari 2019). Tersedia dari:https:// gco.iarc fr /today/data/factsheets/cancers/20-Breast-fact-sheet .pdf

3. International Agency for Reasearch on Cancer. Latest global cancer data. 2018. (diunduh Februari 2019). Tersedia dari:https://www.iarc.Fr/wpcontent/uploads/2018/09/pr263 E.pdf

4. GLOBOCAN. Cancer population fact sheets in Indonesia. 2018. (diunduh Februari 2019). Tersedia dari: $\quad$ https://gco.iarc.fr/today/data/factsheets/ populations/360-indonesia-factsheets. pdf

5. Kementerian Kesehatan Republik Indonesia (Kemenkes RI). Pusat data dan informasi Kementerian Kesehatan Republik Indonesia. 2015. (diunduh Februari 2019). Tersedia dari: http://www.depkes.go.id/resources/download/pusda tin/infodatin/info datin-kanker.pdf

6. Kumar V, Cotran R, Robbin S. Buku ajar patologi volume 1. Edisi ke-7. Prasetyo A, Brahm U, Pendit T, editor. Jakarta: Penerbit Buku Kedokteran EGC. 2007:186-89.

7. Ahmad A, editor. Introduction to cancer metastasis. Alabama: Academic press; 2017.

8. Valic A, Milas I, Mayer L, Setic M, Matijevic V, Stanec M. Prognostic significance of CA 15-3 tumor marker in breast cancer patients. Libri Oncol. 2017; 45(1):1-8.

9. Fejzic H, Mujagic S, Azabagic S, Burina M. Tumor marker CA 15-3 in breast cancer patients. Acta Medica Academica. 2015; 44(1):39-46.

10. ASCO. Answers breast cancer. 2018 (diunduh Februari 2019). Tersedia dari: https://www.asco.org/practiceguidelines/qualityguidelines/guidelines

11. Geng B, Liang MM, Ye XB, and Zhao WY. Association of CA 15-3 and CEA with clinicopathological parameters in patients with metastatic breast cancer. Molecular and Clinical Oncology. 2014;3(1): 232-6.

12. Chen H, Zhou M, Tian W, Meng K, Hehai. Effect of age on breast cancer patients prognoses: A population based study using SEER 18 database. PLosONE.2016;10(11):1-11.

13. Sharma D, Singh G. Breast cancer in young women: A retrospective study from tertiary care center of North India. South Asian J Cancer. 2017;6(2):51-3

14. Breast Cancer. Worse outcome in young women with breast cancer. 2016 (diunduh Juli 2019). Tersedia dari: https://www.Breastcancer.org/research-news/ doyoung-women-have-worse-outcomes.diakses Juli 2019.

15. Rahman M, Mohammer S. Breast cancer metastasis and the lymphatic system (review). Oncology Letter. 2015;10:1233-9
16. Obenauf AC, Massaque J. Surviving at a distant organ specific metastasis. Trends cancer. 2016;1(1): 76-91.

17. Blackburn HL, Ellsworth DL, Shriver CD, Elssworth RE. Breast cancer metastasis to the axilary lymph nodes: Are changes to the lymph node "soil" localized or systemic?. Breast cancer, basic and clinical research. 2017;1-5.

18. El-Abd, El-Sheikh M, El-Zoghby. Plasma TuM2-PK correlates with tumor size, CRP and CA 15-3 in metastatic breast carcinomas; short versus long term follow up study of the egyptian breast cancer patients. cancer biomarkers. 2017;20(2):123-133.

19. JinX, MuP. Targeting breast cancer metastasis. breast cancer: Basic and clinical research. Libertas Academica. 2015;9(1):23-4.

20. Darlix A, Lamy PJ, Lopez-Crepes E, Braccini AL, Firmin N, Romieu G, et al. Serum HER2 extra-cellular daomain, s100b and ca 15-3 levels are independent prognostic factors in metastatic breast cancer patients. BMC Cancer. 2016;16(1):1-14.

21. Stieber P, Nagel D, Blankenburg I, Heinemann V, Untch M, Bauerfeind I,et al.Diagnostic efficacy of CA 15-3 and CEA in the early detection of metastatic breast cancer-A retrospective analysis of kinetics on 743 breast cancer patients. Clinica Chimica Acta. 2015;448: 228-231. 